\title{
An Overview of Biodiversity Conservation in Ghana: Challenges and Prospects
}

\author{
D. K. Attuquayefio ${ }^{1 *}$ and J. N. Fobil ${ }^{2}$
}

'Department of Zoology, University of Ghana, P.O. Box LG 67, Legon-Accra, Ghana ${ }^{2}$ School of Public Health, College of Health Sciences, University of Ghana, LegonAccra, Ghana

* Corresponding author

\begin{abstract}
The Convention on Biological Diversity (CBD), to which Ghana became a signatory in 1992, and other Multilateral International Environmental Agreements enjoin signatory Parties to develop strategies for the conservation and sustainable use of biodiversity. In this regard, there has been a Biodiversity Country Study for Ghana, a National Environmental Action Plan (NEAP) and a National Biodiversity Strategy and Action Plan. Both in situ (use of both traditional and scientific methods - sacred groves and protected areas), and $e x$ situ (gene banks, zoological and botanical gardens) approaches have been used in biodiversity conservation in Ghana. The effectiveness of the former has, however, diminished in recent times because of rapid population growth, urbanization, human migration and resettlement, influence of western technology, foreign religions and beliefs, human encroachment, deforestation, poaching, etc. Ghana's environmental conservation initiatives hold quite promising prospects, especially with the current collaboration between local traditional authorities, NGOs, government institutions, academic and research institutions, and the realization that more flexible multidisciplinary and holistic approaches to biodiversity conservation are more likely to yield better results. The main objective of biodiversity conservation is to ensure that the use of biological resources does not diminish the variety of genes and species, or destroy important habitats and ecosystems worldwide. The major problem facing biodiversity conservation in Ghana today is the rapid population growth and its resultant urbanization, over-exploitation of forests, need for more agricultural land, etc. The current situation needs a serious appraisal of national population programmes, especially in the areas of implementation and censusing, as well as initiation of environmental awareness campaigns involving stakeholders like environmental NGOs, governmental organizations, District Assemblies, traditional authorities, and the mass media. Poverty alleviation programmes targeted especially at rural communities are also steps in the right direction.
\end{abstract}

\section{Introduction}

Throughout the world, there has been increasing interest in environmental issues, especially the current deteriorating state of the global and local environment, largely as a result of undesirable human activities. The current increased rate of biodiversity loss is of special and immediate concern, because of its negative implications for human survival on earth. The loss of each species comes with the loss of potential economic benefits (e.g. natural products that increase world food supply and the medicines humans depend on), as well as a loss of ecosystem balance.

Biodiversity is of both direct (source of food, medicines, construction materials, raw material for industry, recreation, etc.) and indirect(ecological research, education, etc.) benefit to human populations, hence the need to ensure its conservation for posterity. The primary objective of biodiversity conservation is to ensure that biological resources are used in ways that do not diminish the variety of genes and species, or destroy important habitats and ecosystems. Biodiversity conservation can be undertaken in situ (maintenance, protection, and 
management of variety of life in their original habitats), or ex situ (collection and maintenance of whole or parts of individuals of some species or their populations and communities in facilities away from their original habitats) (Oteng-Yeboah, 1997). The establishment of protected areas, gene banks, and zoological/botanical gardens, has been a primary method used in both in situ and ex situ biodiversity conservation.

\section{Why conserve biodiversity?}

It is estimated that about $1 \%$ of the earth's recorded species of higher animals (birds and mammals) have become extinct, with humans being responsible for about $75 \%$ of such extinctions(Fisher, 1971)(Table

TABLE 1

Causes of extinction of birds and mammals since 1600

\begin{tabular}{lcc}
\hline Causes of extinction & Birds (\%) & Mammals (\%) \\
\hline Natural & 24 & 25 \\
\hline Human & 42 & 33 \\
Introduced predators & 15 & 17 \\
Habitat descruction & 15 & 19 \\
Other introductions & 4 & 6 \\
\hline Total & 76 & 75 \\
\hline
\end{tabular}

Adapted from Fisher (1971)

1). About 173 recorded species of birds and mammals, 654 species of plants, and 191 species of molluscs have gone extinct since the year 1600 (Allen, 1972; ICBP, 1980; David, 1981; Honneger, 1981) (Table 2), against the background that only a small percentage ( $1.6 \mathrm{million}$ species of flora and fauna) of the about 5-30 million known species currently left on earth have so far been identified (May \& Marten, 1982). It is quite alarming that the lines of evolution and
TABLE 2

Extinction of plant and animal species (1600 to present)

Taxa

Number of extinct species since 1600

\begin{tabular}{lr}
\hline Mammals & 58 \\
Birds & 115 \\
Reptiles & 19 \\
Amphibians & 1 \\
Molluscs & 191 \\
Plants & 654 \\
\hline Total & 1038
\end{tabular}

Sources: Allen (1972); David (1981); Honneger (1981); ICBP (1980)

ecological relationships that have developed over several millions of years are being suddenly truncated, largely through the activities of only one "exterminator species" on earth, Homo sapiens. There is justifiable concern among conservation experts that many species may become extinct even before they are identified and studied, even though they may hold great potential for expanding and diversifying agricultural production, as well as providing new and effective cures for some current intractable diseases threatening the very survival of the human race (e.g. AIDS, cancer, etc.) (Anon., 1994).

Direct factors that may account for the current human-induced accelerated extinctions and consequent loss of biodiversity include(i) loss or disturbance of habitat through deforestation, desertification and habitat fragmentation, (ii) natural resource over-exploitation through poaching, logging and fuelwood harvesting, (iii) air and waterpollution from industrialchemicals, pesticides and mining, and (iv) introduction of exotic species. Equally critical but indirect 
causes include (i) the current high rates of population increase, especially in the lessdeveloped countries of the world (Table 3), (ii) widespread poverty, (iii) urbanization, proposing the establishment of forest reserves (areas legally constituted for permanent forest production) was drafted in 1911 , but it was not until 1927 that a

TABLE 3

Comparing population growth rates: Ghana and the rest of the world

\begin{tabular}{|c|c|c|c|c|c|c|}
\hline \multirow[t]{2}{*}{ Countries/Regions } & \multicolumn{4}{|c|}{ Population (millions) } & \multirow{2}{*}{$\begin{array}{c}\text { Population } \\
\text { doubling time (years) }\end{array}$} & \multirow{2}{*}{$\begin{array}{c}\text { Population } \\
\text { density }\left(\text { No. } / \mathrm{ml}^{2}\right)\end{array}$} \\
\hline & 1992 & 2000 & 2010 & 2025 & & \\
\hline Ghana & 16 & 18.9 & 26.9 & 35.4 & 29 & 212 \\
\hline Developing World & 4,197 & & 5,782 & 7,155 & 42 & 153 \\
\hline Developed World & 1.224 & & 1,333 & 1.392 & 809 & 60 \\
\hline World & 5,420 & & 7,115 & 8,547 & 51 & 117 \\
\hline
\end{tabular}

Source: Green (1992); Population Reference Bureau (PRB) (2000)

and (iii) weak legislation and institutional structures.

\section{Chronology of biodiversity conservation initiatives in Ghana}

Forest protection

An estimated $70 \%$ of the original closed forest cover of the country had been destroyed at the beginning of the last decade (IIED, 1992), leaving only about $11 \%$ of intact forest, much of which is within protected areas. Much of this deforestation, estimated at about $22,000-75,000$ ha per annum (Hawthorne, 1990) could be largely attributable to forest clearing for cultivation, logging and bush fires.

Efforts at conserving the nation's forest and its resources date back to the turn of the 20 th century, when exploding populations and the associated increased demand for wildlife resources and agricultural land resulted in significant increases in the rate of deforestation. In 1906, legislation was enacted to control the felling of commercial tree species, followed by the establishment of a Forestry Department in 1909. A bill
Forest Ordinance was passed, giving authority to the colonial government to establish forest reserves.

In 1948, a Forest Policy was adopted to fulfil the need for specific guidance and control of forestry activities in the country through (i) the creation and management of permanent forest estates, (ii) research into all branches of scientific forestry, (iii) maximum utilization of areas not dedicated to permanent forestry, and (iv) provision of technical advice and co-operation in schemes for the prevention of soil erosion and in land use plans. A Timber Resource Management Act (Act 547) was enacted in 1997 to provide for the grant of timber rights in a manner that secured the sustainable management and utilization of the country's timber resources. In 1998, the Timber Resource Management Regulations set out procedures for the granting of timber rights followed in 1999 by a Forestry Commission Act (Act 571), which established a Forestry Commission (FC) under which the main public bodies and agencies implementing the functions of protection, development, 
management, and regulation of forest and wildlife resources were required to operate. The specific functions of the FC were to: (i) regulate the utilization of forest and timber resources, (ii) manage the nation's forest reserves and protected areas, (iii) assist the private sector and other bodies with the implementation of forestry and wildlife policies, and (iv) undertake the development of forest plantations for restoration of degraded forest areas, expansion of the nation's forest cover, and the increase in production of industrial timber. The major laws and legislations relevant to forest management in Ghana are listed in Table 4 (MES, 2002).

\section{Wildlife protection}

Wildlife protection initiatives date back to 1901 when colonial governments were enjoined by the 1900 London Convention to ensure sustainable exploitation and management of game. Initiatives to establish the first game reserves started in 1909 , but these did not materialise until the Department of Game and Wildlife was established from the Game Unit of the Forestry Department, which had been in existence since 1957. This was preceded by the enactment of the Wildlife Preservation Act (Act 43) in 1961, the parent legislation on which all future wildlife regulations in the country were based (Ntiamoa-Baidu et al., 2001). This Act empowered the President to enact wildlife protection legislation, and set out five schedules of animals to be given various degrees of protection and control. The Department of Game and Wildlife had the mandate to manage the country's wildlife resources both within and outside Forest Reserves.

Subsequent to the Wildlife Preservation Act (1961), several legislations and corresponding amendments have been

TABLE 4

Environmental laws/regulations regarding forest management

\begin{tabular}{ll}
\hline Law/Regulation & Year(s) \\
\hline Forest Ordinance (Cap 157) & 1927,1929 \\
Forest Protection Decree NRCD 243 (Amendment) & $1927,1974,1983$ \\
Trees and Timber Ordinance & 1949 \\
Trees and Timber Regulations NRCD 273 (Amendment) & $1950,1951,1961,1991$ \\
Trees and Timber (Amendment) Act & 1957,1974 \\
Protected Timber Lands Act (Act 34) & 1959 \\
Forest Offences Act (Act 83) & 1959 \\
Timber Lands Regulations & 1959 \\
Trees and Timber Decree (Amendment) & 1974,1983 \\
Forest Fees Regulations (LI 1098) & 1976 \\
Economic Plants Protection Decree (AFRC 47) & 1977,1979 \\
Forest Protection (Amendment) Law (PNDCL 142) & 1986 \\
Prevention and Control of Bushfires Law & 1990 \\
Timber Resource Management Act (Act 547) & 1997 \\
Timber Resource Management Regulations (LI 1649) & 1998 \\
Forestry Commission Act (Act 571) & 1999 \\
\hline
\end{tabular}


nacted over the years to address specific spects of wildlife conservation, including he establishment of various wildlife onservation areas (Ntiamoa-Baidu et al.,
2001) (Table 5). The Wild Animal Preservation (Game Reserves) Regulation (LI 171) (1962) established the Mole and Shai Hills Game Reserves and the Owabi

TABLE 5

Ghana's Wildlife Laws

aws/Regulations
Wild Animals Preservation
Act (Act 43)
Wild Animals Preservation
(Game Reserves) Regulations
(Ll 171)

Wildlife Reserves Regulations (LI 710)

Wildlife Conservation

Regulations (LI 685)

Wildiife Reserves (Amendment) Regulations (LI 881)

Wildlife Reserves (Amendment) Regulations (LI 1022)

Wildlife Reserves (Amendment) Regulations (LI 1084)

Wildlife Reserves (Amendment) Regulations (LI 1085)

Wildlife Reserves (Amendment) Regulations (LI 1 105)

(). Wildlife Reserves (Amendment) Regulations (LI 1284)

1. Wildlife Reserves (Amendment) Regulations (LI 1357)

12. Wildlife Reserves (Amendment) Regulations (LI 1452)
Year

1961

1962

1971

Repealed LI 171 and established Mole, Digya, and Bui National Parks, Shai Hills Game Production Reserve, Owabi Wildlife Sanctuary, and Kogyae Strict Nature Reserve

1971 Outlined hunting restrictions game licenses, game/ trophy export permits, and listed schedules of animals protected in Ghana

1974 Amended LI 710 to established Bia National Park

1975 Amended LI 710 to establish Bomfobiri Wildlife Sanctuary and Kalakpa and Gbele Game Production Reserves

1976 Amended LI 710, downgraded part of Bia National Park to two Game Production Reserves (Bia West and Bia South) to allow logging, and established Nini-Suhien National Park and Ankasa Game Production Reserve

Amended LI 710 and combined Bia West and Bia South Game Production Reserves into a single Bia Game Production Reserve

1983 Amended LI 685 by making possession of protected animals illegal, defining new fines/fees and amending the First and Second Schedules of protected species

1988

1989 Amended LI 685 by abolishing group hunting and instituted a license for trading in wild animals and keeping them as pets 
Waterworks, and prohibited some activities (e.g. close-season restrictions) in game reserves. L1 171 was repealed in 1971 by the Wildlife Reserves Regulation (LI 710), which established the Digya and Bui National Parks, and converted Owabi Waterworks to a Wildlife Sanctuary, Mole Game Reserve to a National Park, and Shai Hills Game Reserve to a Resource Reserve. LI 7:10 also outlined basic park management guidelines, and prohibited hunting and plant collection from legally-constituted reserves, through several amendments over the years: LI 881 (1974), LI 961 (1974), LI 1022 (1975), LI 1084(1976), LI 1085(1976), and LI 1105 (1977). Again in 1971, the Wildlife Conservation Regulations (LI685) outlined restrictions on hunting, game licenses and game/trophy export permits, and listed schedules of protected animals in Ghana. LI 685 underwent several amendments, notably LI 1284(1983), LI 1357(1988) and LI 1452(1989)(Ntiamoa-Baidu et al., 2001; Ampadu-Adjei, 2002) (Table 5).

With the adoption of the first National Wildlife Policy in 1974, and its revision in 1994 , the roles of protected areas were defined and new wildlife conservation areas were established. In 1993, a joint National Forest and Wildlife Policy was formulated in recognition of the inextricable link between forest and wildlife, and the need to outline the principles and objectivesto guide the sustainable development of both sectors in order to maintain the ecological balance and biodiversity of the natural environment.

Environmental awareness and

Ghana's economic development:

National Environmental Action Plan (NEAP)

The need to ensure a sustainable socio- economic development of the country in the long term, necessitated the balancing of national development efforts and the quest for economic growth with a rational exploitation of the natural resource base. The Government of Ghana, thus, established the Environmental Protection Council(EPC) in 1974 to: (i) advise on, and conduct research into, environmental issues, (ii) coordinate national efforts at environmental improvement, and (iii) establish guidelines for the wise use of Ghana's natural resources. Since the EPC lacked powers of enforcement, it was largely ineffective in ensuring sustainable biological resource utilisation in Ghana, and was also ill-equipped to deal with the environmental problems created by individuals and corporate bodies bent on maximising economic profits under Ghana's Economic Recovery Programme (ERP) initiated in 1982 (Sarpong, 1996).

The ERP, which emphasised the implementation of some drastic economic measures to ensure the acceleration of economic growth further aggravated the problems of biodiversity conservation in Ghana. This was mainly due to the activities of companies in the mining and agricultural sectors, which resulted in increased rates of habitat loss, and pollution of both surface and underground water, soil and air. Environmental degradation and the depletion of biological resources became even more pronounced in the late $1980 \mathrm{~s}$ as population increased. Attempts at readjustment to the shock of serious economic stagnation in the late 1970 s and early 1980 s resulted in human resettlement programmes which, in turn, placed increasing demands on land and its attendant problems of rapid urbanisation and other environmental problems.

Biodiversity conservation initiatives in 
Ghana received a big bo ssi in March 1988 , when the government initiated a major effort to bring environmental issues to the forefront of national development efforts. A National Environmental Action Plan (NEAP) was formulated to provide the foundation for national environmental polices. Volumes 1 and 2 of the NEAP were compiled in 1991 and 1994, respectively, with the former proposing the establishment of a legal system including an Environmental Impact Assessment (EIA), various standards and regulations, and cievelopment of guidelines and an information system. The latter outlined the status of biodiversity in environmental policies. The adoption and implementation of the EIAs in 1989 partially stabilized the increasing rate of biodiversity depletion caused by implementation of the ERP.

The new developments provided the impetus for the creation of a new Ministry of Environment, Science and Technology (MEST), and necessitated a redefinition of the functions of the EPC to avoid duplication and overlap of functions. This led to the establishment of the Environmental Protection Agency (EPA) in 1994 (Act 490) to replace the EPC. The transformation was to ensure a more efficient policy formulation, planning, monitoring, problemsolving and implementation with regard to the utilization of national biological resources. In February 1999, under the auspices of the Ministry of Local Government and Rural Development, the government introduced a National Sanitation Policy document to address the problems of pollution arising from unsanitary practices and conditions prevailing in the country. This document provided a list of suggested policies earmarked for implementation by the various Municipal and District Assemblies, with the ultimate objective of ensuring minimization of waste and abatement of pollution from commerce, industry and households.

International conventions relevant to biodiversity conservation in Ghana

The threat to global ecosystems by human activities, and the recognition that the solution to environmental problems required international collaboration led Ghana to be Party to a number of international conventions and agreements related to biodiversity and the environment (Table 6). To date, there are 216 such conventions, with Ghana being signatory to 35 of them, including all the major conventions on biodiversity conservation. Ratification enjoined Parties to initiate certain prescribed activities at the national level, but due largely to the absence of an institutional framework for harmonizing the different sectoral biodiversity initiatives through appropriate national or domestic legislation, there have been problems with enforcement and implementation. In Ghana, there have been serious efforts to inventory, review and reconcile all existing regulations on the environment and biodiversity with the objective of developing general laws on the environment and biodiversity (MES, 2002). ANationalBiodiversity Commission(NBC) has been established and tasked with overall responsibility for formulation, co-ordination and execution of programmes and policies on biodiversity, as well as promoting the necessary international co-operation with donor agencies and neighbouring countries.

\section{Convention on wetlands of}

international importance, especially as waterfowl habitat (Ramsar

Convention)

The Ramsar Convention, adopted on 2 
Convention on Wetlands of International Importance, Especially as Waterfowl

Habitat (Ramsar Convention)

2 February 1971

Convention on International Trade in Endangered Species of Wild Fauna and

Flora (CITES)

3 March 1973

Convention on the Conservation of Migratory Species of Wild Animals (Bonn

Convention- CMS)

23 June 1979

Convention on Biodiversity (CBD)

June 1994

Convention on the Conservation of African-Eurasian Migratory Waterbirds (AEWA) 1999

United Nations Convention on the Law of the Sea

10 December 1982

Montreal Protocol on Substances that Deplete the Ozone Layer

16 September 1987

Vienna Convention for the Protection of the Ozone Layer

24 July 1989

United Nations Convention to Combat Desertification in those Countries

Experiencing Serious Drought and/or Desertification, Particularly in Africa (UNCCD) 1996

UNESCO Man and the Biosphere Programme (MAB)

February 1971 at Ramsar in Iran, came into force on 21 December 1975, and currently has 122 contracting Parties. It provided the framework for international co-operation for conservation and wise use of wetlands, and required the contracting Parties to: (i) designate suitable wetlands within their territories for a List of Wetlands of International Importance (Ramsar Sites) (Article 2.1), (ii) formulate and implement planning to promote the conservation of wetlands listed, and, as far as possible, wise use of the wetlands in their territory (Article 3.1), (iii) promote conservation of the wetlands and waterfowl by establishing nature reserves on wetlands (included or not) and provide adequately for their wardening (Article 4.1). Ghana became Party to the Convention in 1988, with the establishment of the Owabi Ramsar Site (Ashanti Region). Since then, five other coastal Ramsar Sites (Keta, Songor, Sakumo, Densu and Muni-Pomadze) have been established.

Serious wetland conservation efforts in Ghana started in 1991, with the publication of a management strategy document for Ghana's coastal wetlands (Ntiamoa-Baidu \& Gordon, 1991). This documentessentially outlined the importance of, and threats to, Ghana's coastal wetlands, and provided recommendations on strategies to maintain the ecological integrity of these wetlands. In 1994, the Ghana Coastal Wetlands 
Management Project (CWMP) was commissioned with the objective of restoring and maintaining the ecological integrity of the five coastal Ramsar sites in Ghana. A National Wetlands Strategy was also initiated with the ultimate goal of conservation and sustainable use of the country's wetland resources through documenting strategies for incorporating wetland management into activities of government, organizations, traditional authorities, communities and individuals within the broader context of environmental management (MLF, 1999).

African convention on the conservation of nature and natural resources

This Convention was signed in Algiers on 15 September 1968 , and came into force on 7 March 1969. It enjoined Parties to: (i) adopt measures necessary to ensure conservation, utilization and development of soil, water, floral and faunal resources in accordance with scientific principles, and with due regard to the best interests of the people, (ii) accord special protection to those animal and plant species threatened with extinction, or which may become so, and to the habitat necessary for their survival, (iii) establish conservation areas: Ghana became party to the Convention in 1968, and established categories of conservation areas based on the definitions set out in the Convention.

Convention on international trade in endangered species of wild flora and fauna (CITES)

The Convention was adopted on $6 \mathrm{March}$ 1973 in Washington DC, USA, and entered into force on 1 July 1975 with 154 contracting Parties. Its major objective is the protection of threatened species from detrimental effects of international trade through the regulation of trade in specific plants and animals to prevent their excessive exploitation. CITES listings include some 30,000 plants and 2,500 animal species grouped under three Appendices (Moulton \& Sanderson, 1997). Appendix I species are threatened with extinction and, therefore, cannot be traded in. Appendix II species are not yet threatened with extinction, but might soon be, so levels of trade in them are limited. Appendix III species are nationally threatened, and are protected within the borders of individual nations with international support(Moulton \& Sanderson, 1997). Ghana signed the Agreement on 16 December 1975, and ratified it on 14 November 1976.

Convention on the Conservation of Migratory Species of Wild Animals (Bonn Convention)

Adopted in Bonn, Germany on 23 June 1979, it entered into force on 1 November 1983 with 74 contracting Parties. Its main objective is to protect migratory species, especially threatened ones, in recognition of the fact that such species need protection throughout every part of their migratory ranges. The Convention groups migratory species into two Appendices. Appendix I species are in danger of extinction throughout all, or a significant part of their range, and, where feasible and appropriate, range states are enjoined to conserve such species, and to restore those habitats of the species which are important in removing the species from danger of extinction (Article III 4a). Appendix II species could benefit from international co-operation in their conservation and management, with range nations obliged to, where appropriate and 
feasible, provide for the maintenance of a network of suitable habitats appropriately disposed in relation to migration routes. Ghana became Party to the Convention in 1988 , and fulfilled her obligations by placing all terns (Sturnidae) on the country's list of wholly-protected species.

\section{Convention on Biological Diversity (CBD)}

In recognition of the urgency of tackling the problems associated with biodiversity conservation worldwide, the Governing Council of the United Nations Environmental Programme (UNEP) in 1987 and 1989 convened two Ad Hoc Working Groups of Biodiversity Experts to harmonise existing Conventions relating to biodiversity, and to prepare an international legal document for conservation and sustainable use of biological diversity. This document became the Convention on Biological Diversity (CBD), which was unveiled at the "Earth Summit" in Rio de Janeiro, Brazil, in June 1992. The Convention came into force in December 1993, with Ghana ratifying it on 29 August 1994 as the 12th out of 157 signatory Parties. As at July 2001, there were 181 signatory Parties of the CBD, whose principal objectives are the (i) conservation of biodiversity, (ii) sustainable use of its components, and (iii) fair and equitable sharing of benefits arising from the utilisation of genetic resources (SCBD, 2001).

Article 6 of the CBD enjoined signatory Parties to develop national strategies for the conservation and sustainable use of their biological diversity, in pursuance of which a National Biodiversity Strategy and Action Plan document has been produced (MES, 2002). Article 7 (a) also committed signatory Parties to undertake biodiversity inventories to obtain basic information on the distribution and abundance of biodiversity (UNEP, 1992; Stork \& Samways, 1995). In this regard, a Ghana Biodiversity Country Study has been undertaken with the objectives of (i) providing baseline information on the country's biodiversity, and (ii) identifying a number of measures to be instituted to ensure conservation and sustainable use of the nation's biological resources.

Efforts to implement biodiversity conservation programmes through sound environmental practices and sustainable resource utilization have involved collaborative research projects between the Wildlife Division (Forestry Commission) and counterpart departments in the various universities, research institutes and some environmental NGOs, notably the Ghana Wildlife Society (GWS), Friends of the Earth (FOE), Green Earth Organisation and Conservation International.

United Nations Framework Convention on Climate Change (UNFCCC)

One of the most widely-accepted global conventions, the UNFCCC, was adopted in 1992 and entered into force in 1994 with 182 contracting Parties. Its main objective is to stabilize greenhouse gas concentrations in the atmosphere at a level that would prevent dangerous anthropogenic interference with the climate system; such a level should be achieved within a time-frame sufficient enough to allow ecosystems to adapt naturally to climate change.

United Nations Convention to Combat Desertification in those Countries Experiencing Serious Drought and/or Desertification, particularly in Africa (UNCCD)

The Convention was adopted in 1994 and 
entered into force in 1996 with 175 contracting Parties. Its major objective is to combat desertification and mitigate the effects of drought, using national and regional action programmes. It employs a bottom-up approach, which encourages local, national and regional levels of NGOs, and local populations in policy planning and decisionmaking (Article 10).

\section{UNESCO Man and the Biosphere Programme (MAB)}

The aim of UNESCO-MAB is to develop a basis within the natural and social sciences for the sustainable use and conservation of biodiversity, and for improvement of the relationship between people and their environment globally. It operates globally through a network of Biosphere Reserves nominated by national governments and internationally recognized. As at March 2001, there were 393 Biosphere Reserves in 94 countries worldwide. In Ghana, the Bia National Park has been designated a Biosphere Reserve, and a UNESCO-MABEPA Man and Biosphere National Committee has been set up with the mandate to promote development-oriented research and the application of the results to enhancement of biodiversity conservation and sustainable development and improvement in people's livelihood in Biosphere Reserves.

Convention concerning the Protection of the World Cultural and Natural Heritage "UNESCO-World Heritage" Convention -WHC)

Adopted on 16 November 1972, it entered into force on 17 December 1975 , with 164 signatory parties. Its main objective is the protection of natural and cultural areas considered to be of such outstanding universal or exceptional value that their protection must concern humankind, and, thus, international co-operation is needed for their effective protection. The assessment of natural sites for protection is by a World Heritage Committee established by the World Conservation Union (IUCN). Contracting parties are enjoined to protect designated sites through contributions to a World Heritage Fund. In Ghana, the cultural sites are taken care of by the Ghana Museums and Monuments Board(GMMB), while the natural sites are under the control of the Wildlife Division(WD) of the Forestry Commission.

Approaches to biodiversity conservation in Ghana

Current approaches to biodiversity conservation have focused on the harmonious fusion of modern scientific strategies (research and environmental education) and cultural and traditional methods. Cultural and traditional biodiversity conservation methods are still relevant, since they cover the broadest range of society, and are particularly useful in less-developed countries where the majority of the population lack formal education. Because of the tendency to downplay the critical link between traditional and scientific conservation approaches, most conservation initiatives in developing countries, including Ghana, have not been too effective.

Traditional biodiversity conservation

The African traditional concept of land ownership enjoined the living to manage and conserve the environment for future generations", while accounting for such stewardship to their ancestors (Abayie 
Boaten, 1997). As Danquah (1968) stated “.......in our culture, we do not only hold in trust for the present and future generations all the natural resources on which our welfare and continuance of the community depend, but also are accountable to the ancestors for the proper management of the resources". Before the CBD came into force, traditional African societies maintained complex religious and cultural belief systems that guided the conservation of biodiversity using traditional norms such as taboos and myths to ensure the preservation of certain critical and finite resources. In some rural and even urban areas of Ghana, taboo days for farming, fishing and hunting are still widely observed, with many water bodies being worshipped as deities. Such traditional practices enabled the protection of biological resources from human disturbances and wanton over-exploitation.

The establishment of sacred groves, defined as "small patches or islands of remaining original habitat" or "traditionallyprotected tracts of land of varying sizes that may be as old as mankind"'(Kingdon, 1989), ensured that forests surrounding and protecting water courses and other environmentally-sensitive areas were demarcated and protected as shrines. They range in size from hundreds of hectares of forest to single trees or a few stones (Gordon, 1992), and, because of their perceived links to some divine deities or ancestral spirits, are referred to variously as "nananom mpow" (ancestral groves) (AdarkwaDadzie, 1997), abosompow/asoneyeso (shrine), mpanyinpow (ancestral forest), and nsamanpow (burial grounds) by the Akans (Ntiamoa-Baidu, 1995). Sacred groves serve important ecological and socio- cultural functions by preserving virgin forests, being important refuges for rare and useful local biodiversity, and being sources of herbs for medicinal, social and religious purposes (Dorm-Adzobu et al., 1991; Decher, 1997). There are an estimated 2,000 -3,200 sacred groves in Ghana, about 80 per cent of which occur in the southern half of the country (Gordon, 1992).

Because of the linkage between traditional beliefs and divine deities or ancestral spirits, disobedience or disregard of traditional laws (taboos) attracts severe punishments for culprits, and high prices of atonement, including making sacrifices and performing certain rites toavert any mishaps, ill-health and death. Unfortunately, this has not been effective deterrent for the reckless use of biological resources by local communities due to (i) rapid population growth and its attendant problems of urbanization, migration, and resettlement, (ii) increased dependence on western technology, and (iii) the growing influence of foreign religions and beliefs (Decher, 1997).

Modern approaches to biodiversity conservation

In situ conservation. Modern in situ conservation approaches utilize all the legal protected areas in Ghana, notably forest reserves, wildlife conservation areas, and Ramsar sites. Currently, there are 280 forest reserves in Ghana under the management of the Forest Services Division (Forestry Commission), covering a total area of about $23,729 \mathrm{~km}^{2}$, or $11 \%$ of the total land area of Ghana. About $75 \%$ of these reserves have been designated production reserves, which are exploited for timber, while the remaining $25 \%$ are protection reserves, 
which are not currently under exploitation, probably because of inaccessibility (MES, 2002). There are 21 legally-constituted wildlife conservation areas, notably six narional parks, six resource reserves, three wildlife sanctuaries, and one strict nature reserve. There are also two proposed wildlife conservation areas (one national park and one wildlife sanctuary), as well as six Ramsar sites under the management of the Wildlife Division (Forestry Commission) (Table 7). Such large-scale protected areas are critical to the protection of many large wildlife species, especially elephants, bovids, primates, and carnivores (Decher, 1997).

Recently, some innovations in biodiversity conservation have been introduced, with the establishment of Globally Significant Biodiversity Areas (GSBAs), Important Bird Areas (IBAs), and Community Resource Management Areas (CREMA). The Forestry Services Division has currently designated 29 Forest Reserves as GSBAs, because of their importance as habitats for globally-significant biodiversity, whose commercial exploitation is prohibited and local community participation in management is encouraged (MES, 2002). IBAs operate under the concept of birds as importantbio-indicators, and were developed to conserve wildlife protected areas, some off-reserve areas, and forest reserves that harbour nationally or globally important birds and other biodiversity. The GWS, in collaboration with BirdLife International, has currently identified 36 IBAs covering about $11,494 \mathrm{~km}^{2}$ (about $4.8 \%$ of the total land area of Ghana). The CREMA concept was initiated by the Wildlife Division under its Protected Areas Development Programme (PADP) to encourage communities bordering protected areas to manage and sustainably utilize wildlife resources within a defined area through a Community Participatory Approach (Wildlife Division, 1998).

Unfortunately, in situ conservation has suffered from encroachment by local communities for farming, hunting and settlement purposes, causing widespread deforestation. There are also administrative problems arising from low government budgetary allocations, inadequate staffing, and lack of infrastructure and basic field equipment. One way to tackle the problems is to ensure that future protected areadriven biodiversity initiatives are collaborative efforts between the relevant government agencies, on the one hand, and all the majorstakeholders, especially industry, NGOs, traditional authorities and local communities, on the other.

\section{Ex situ conservation}

Ex situ conservation utilizes zoos, botanical gardens, and genetic resource centres (gene banks) to undertake captive breeding programmes for some species for later introduction into the wild to re-stock dwindling natural populations. Currently, the major ex situ conservation facilities in Ghana are located at the (i) University of Cape Coast (Botany Department Herbarium), (ii) University of Ghana (Zoology Department Entomology Museum, Botany Department Herbarium and Botanical Gardens and Noguchi Memorial Institute of Medical Research), (iii) Kwame Nkrumah University of Science and Technology Botanical Gardens and Forestry Herbarium, (iv) Accra Zoo, (v) Kumasi $\mathrm{ZoO}_{2}$ (vi) Aburi Botanical Gardens, (vii) Bunso Plant Genetics Research Centre and 
TABLE 7

Wildlife conservation areas in Ghana

\begin{tabular}{|c|c|c|c|c|}
\hline Type & Name & Area $\left(\mathrm{km}^{2}\right)$ & Year & Location/Region \\
\hline \multirow[t]{7}{*}{ National Park } & Mole & 4,840 & 1971 & Northern \\
\hline & Digya & 3,478 & 1971 & Volta/Ashanti \\
\hline & Bui & 1,821 & 1971 & $\begin{array}{l}\text { Northern/Brong- } \\
\text { Ahafo }\end{array}$ \\
\hline & Kyabobo & 360 & Proposed & Volta \\
\hline & Kakum & 207 & & Central \\
\hline & Nini-Suhien & 160.2 & 1976 & Western \\
\hline & $\mathrm{Bia}$ & 78 & 1977 & Western \\
\hline \multirow[t]{4}{*}{ Wildiife Sanctuary } & Bomfobiri & 53 & 1975 & Ashanti \\
\hline & Owabi & 13 & 1971 & Ashanti \\
\hline & Buabeng-Fiema & 4.4 & 1974 & Brong-Ahafo \\
\hline & Agumatsa & 3 & Proposed & Volta \\
\hline \multirow{6}{*}{ Resource Reserve } & Gbele & 565 & 1975 & Upper West \\
\hline & Ankasa & 343 & 1976 & Western \\
\hline & Kalakpa & 320 & 1975 & Volta \\
\hline & $\mathrm{Bia}$ & 228 & 1977 & Western \\
\hline & Assin-Attandaso & 140 & & Central \\
\hline & Shai Hills & 49 & 1971 & Greater-Accra \\
\hline Strict Nature Reserve & Kogyae & 386 & 1971 & Ashanti \\
\hline \multirow[t]{6}{*}{ Ramsar Site } & Keta Lagoon Complex & 1,200 & & Volta \\
\hline & Songor & 330 & & Greater-Accra \\
\hline & Muni-Pomadze & 90 & & Central \\
\hline & Densu Delta & 70 & & Greater-Accra \\
\hline & Sakumo & 35 & & Greater-Accra \\
\hline & Owabi & 13 & & Ashanti \\
\hline Total area & & 14,173 & & \\
\hline
\end{tabular}

\section{National Parks}

Large and relatively undisturbed areas of outstanding beauty containing representative samples of major natural regions, features or scenery, and containing one or several ecosystems, and not materially altered by man. They combine protection with a public function ("richness of nature").

\section{Strict Nature Reserve}

Relatively small areas containing fragile habitats, outstanding ecosystems or natural features in a relatively undisturbed state, and which are prime representatives of the scientific study, monitoring, education or conservation of biological/cultural resources. They provide maximum protection, with special permits needed for scientific purposes only.

\section{Wildlife Sanctuaries}

Relatively small areas used to protect plant or animal species, either resident or migratory, of exceptional conservation interest, from any form of destruction. They provide visitation rites, but hunting is prohibited.

\section{Resource Reserves}

Areas of variable size, which are managed to guarantee conditions essential to the well-being of selected species for the sustained production of wildlife products for cultural practices, tourism and trophyhunting. Essentially established to increase game populations as a source of protein (formerly Game Production Reserve).

\section{Ramsar Sites}

Wetlands set aside for conservation because of their international importance according to set criteria, and managed to provide maximum benefits to the local communities living within and around the area. 
Arboretum, and (viii) Akropong Centre for Scientific Research into Plant Medicine Herbarium and Arboretum (MES, 2002).

\section{Challenges and prospects of} biodiversity conservation in Ghana Challenges

One of the major problems facing current biodiversity conservation initiatives in Ghana is the rapid rate of population growth and its resultant rapid urbanization and growing poverty levels. The country's population doubling time of 22 years is one of the fastest, compared to the world's average of 41 years (Green, 1992) (Table 4). The strong link between poverty and environmental degradation has been acknowledged. Poverty forces poor rural communities to adopt practices and use technologies that destroy the environment and result in biodiversity loss.

Sub-Saharan Africa contains the highest percentage of people living in abjectpoverty (Mekasha, 2001). Ghana's poverty level stands at about $31 \%$ of the population (MLF, 2000), majority of whom inhabit the three northern regions (Songsore, 1992). Government's efforts to promote economic growth and social development included the implementation of a structural adjustment and economic recovery programme to alleviate the plight of the rural poor and the vulnerable in society in the early 1980s. Unfortunately, this initiative impacted negatively on the predominantly agricultural rural population, because of the removal of subsidies on agricultural inputs, and the abolition of minimum guaranteed prices for agricultural products, which were among the preconditions for funding by the international donors.

The Programme of Actions to Mitigate the Social Costs of Adjustment (PAMSCAD), aimed at the rural poor, was largely ineffective, because it did not benefit the majority of the targeted rural poor and suffered from inadequate funding (Francis, 1992, Asenso-Okyere, 2001; Asiedu, 2002). Other challenges facing biodiversity conservation in Ghana include the lack of adequate manpower and resources to manage existing protected areas and to enforce legislation, as well as the inadequate or lack of co-ordination of conservation initiatives among the various sectoral agencies.

\section{Prospects}

A vision of the Government of Ghana for the next decade is to transform the country to middle-income status where people live in harmony with the natural environment and derive optimum benefits through sustainable use of the country's rich biodiversity. This is in recognition of the important role that biological resources play in national efforts towards the realisation of socio-economic and cultural growth and development (MES, 2002). The prospects of Ghana's biodiversity conservation initiatives are thus, quite promising, especially with several environmental NGOs and other stakeholders assisting in government's efforts at biodiversity conservation. Such collaborative efforts involving local communities, traditional authorities, NGOs, and government institutions are in the right direction. For such efforts to succeed, however, future conservation policies would have to deviate from the past individualistic and rather stereotyped approaches to more flexible multidisciplinary and holistic approaches. For example, the Ramsar and IBA concepts, which focus on the 
preservation of bird habitats in selected protected areas, have the ultimate goals of general biodiversity conservation in all manner of habitats. The current collaboration of academic departments of the universities, research institutions, government departments and NGOs in biodiversity conservation initiatives should also be encouraged.

Fortunately, poverty reduction/alleviation has been receiving serious government attention through several initiatives. One such initiative is the Ghana Poverty Reduction Strategy (GPRS), which seeks to ensure sustainable and equitable growth, accelerated poverty reduction and protection of the vulnerable. It identifies five pillars of development through investment in (i) infrastructure, (ii) agricultural mechanization, (iii) education, health and sanitation, (iv) private sector development, and ( $v$ ) the rule of law and respect for human rights. Other initiatives include the Emergency Social Relief Programme (ESRP), District Assemblies Common Fund (DACF) and the Village Infrastructure Project (VIP), all aimed at enhancing the quality of life of the country's rural poor. However, care should be taken in their implementation to avoid the problems that beset the PAMSCAD and rendered it ineffective.

It is generally accepted that without funding, the most elaborate biodiversity conservation initiative will not achieve the desired results. There is the potential for generation of funding for conservation projects both locally and globally through (i) protected area fees, ( (ii) institution of a Biodiversity Trust Fund, (iii) the private sector and local NGOs, and(iv) international sources like the Global Environmental Facility (GEF) of the World Bank,
Convention of Biological Diversity (CBD), Multilateral/Bilateral financial institutions, donor countries and international NGOs.

\section{Conclusion and recommendations}

As we enter a new millennium, it is envisaged that the challenges to biodiversity conservation are going to be more daunting The effort to provide an even higher quality of life for Ghanaians would place even more stress on the environment if nothing is done to ensure that the economic development of the country went hand-inhand with environmental conservation efforts. In this regard, the following are recommended:

1. Institution of some precautionary anc remedial measures aimed at ensuring that the nation proceeds on its curren developmental path mindful of both the potential and real threats to the environment.

2. Priority attention given to national population programmes, with periodic reviews to ensure their effectiveness and upgrading of the population statistics through comprehensive national population censuses.

3. Initiation of massive environmental awareness campaigns, especially targeting rural communities and the youth, to sensitise such communitie: to the idea of biodiversity conservation as a tool for national survival and the formation of nationwide wildlife club: by the Ghana Wildlife Society (GWS) which is especially targeted at the youth, both in formal and informal settings.

4. Forging of closer collaboration between Ghana and the internationa community in the quest for the 
conservatıon and sustaınable utilization of the country's natural resources to attract, for mutual benefit, the needed funding, technology, techniques and management, especially of boundary resources; specifically, there should be enactment of relevant bi-lateral or multilateral treaties, especially with our shared-border countries(i.e. Togo, La Cote d'Ivoire and Burkina Faso).

5. Demonstration of political commitment on the part of the Government to carry out policies and programmes relevant to biodiversity conservation, through a collaborative effort between government and other stakeholders in biodiversity conservation.

\section{References}

Abayie Boaten B. A. (1997). Traditional Conservation Practices: Ghana's Example. Paper Presented at a UNESCO MAB Seminar on Biosphere Reserves for Biodiversity Conservation and Sustainable Development in Anglophone Africa (BRAAF). Cape Coast, Ghana.

Adarkwa-Dadzie A. (1997). The Contribution of Ghanaian Beliefs to Biodiversity Conservation. Paper Presented at a UNESCO MAB Seminar on Biosphere Reserves for Biodiversity Conservation and Sustairable Development in Anglophone Africa (BRAAF), Cape Coast, Ghana.

Allen G. M. (1972). Extinct and Vanishing Animals of the Western Hemisphere. Cooper Square Publishers.

Ampadu-Adjei O. (2002). The Role of Totems in the Bushmeat Extinction Prevention Campaign in Ghana. Conservation International, Ghana.

Anonymous (1994). Systematics Agenda 2000: Charting the Biosphere. Technical Report of the Global Initiative to Discover, Describe, and Classify the World's Species. New York. Asenso-Okyere K. (2001). Wealth Accumulation. Utilization and Retention: A Converse to Treatise on Poverty Reduction. Ghana Universities Press, Accra.

Asiedu A. B. (2002). Making eco-tourism more supportive of rural development in Ghana.

West Afr. J. appl. Ecol., 3: 1-16.

Danquah J. B. (1968). The Akan Doctrine of God. Frank Cass, London.

David D. (1981). The Doomsday Book of Animals. Viking, New York.

Decher J. (1997). Conservation, Small Mammals, and the Future of Sacred Groves in West Africa. Biodiver. Conserv. 6: 1007-1026.

Dorm-Adzobu C., Ampadu-Adjei O. and Veit P. G. (1991). Religious Beliefs and Environmental Protection: The Malshegu Sacred Grove in Northern Ghana. World Resources Institute, Washington DC and Nairobi. African Centre for Technology Studies (ACTS) Press.

Fisher J. (1971). Wildlife in Danger. In Man's Impact on the Environment (T.R. Detwyler, ed.), pp. 625-635. McGraw-Hill, New York.

Francis F. A. (1992) Structural Adjustment in Africa: Theoretical and Practical Issues. In Planning African Growth and Development: Some Current Issues. (E. Aryeetey), pp. 90113. ISSER/UNDP Publication, Accra.

Gordon C. (1992). Sacred Groves and Conservation in Ghana. Newsletter of the IUCN SSC African Reptile and Amphibian Specialist Group 1: 3-4.

Green C. P. (1992). The environment and growth: decade for action. Supplement to Population Reports, Series M, No. 10 (Vol. $\mathrm{XX}$, No. 2).

Hawthorne, W. D. (1990). Field Guide to the Forest Trees of Ghana. Natural Resources Institute, Chatham.

Honneger R. (1981). List of amphibians and reptiles either known or thought to have become extinct since 1600. Biol. Conserv. 19 (2): 141-158.

International Council For Bird Preservation 
(ICBP)(1980). Red Data Book of Endangered Birds. Smithsonian Institution Press, Washington, D. C.

International Institute for Environment and Development (IIED) (1992). Environmental Synopsis of Ghana. Overseas Development Administration (ODA), London.

Kingdon J. (1989). Island Africa: The Evolution of Africa's Rare Animals and Plants. Princeton University Press, Princeton, N.J.

May J. and Marten M.(1982).AnimalOddities: An $A-Z$ of the Weird and Wonderful. Book Club Associates, London.

Mekasha A. (2001). Microfinance Institutions and their Impact on Wealth Creation. $A D B$

Bull. 4 (5): 5-7.

Ministry of Environment and Science (MES) (2002). National Biodiversity Strategy for Ghana. Government of Ghana, Accra.

Ministry of Environment and Science (MES) (2003). Action Plan for the Implementation of the National Biodiversity Strategy. Government of Ghana.

Ministry of Lands and Forestry (MLF)(1994). Forest and Wildlife Policy. Government of Ghana, Accra.

Moulton M.P. and Sanderson J. (1997). Wildlife Issues in a Changing World. St. Lucie Press, Delray Beach, Florida.

Ntiamoa-Baidu Y. (1995). Indigenous versus Introduced Biodiversity Conservation Strategies: The Case of Protected Area Systems in Ghana. Biodiversity Support Program (Issues in African Biodiversity No. 1). Washington, DC.

Ntiamoa-Baidu Y. andGordon C.(1991).Coastal Wetlands Management Plans: Ghana. Department of Zoology, University of Ghana, Accra. Report to World Bank.

Ntiamoa-Baidu Y., Owusu E. H., Daramani D. and Nuoh A. (2001). Ghana. In Important Bird Areas in Africa and Associated Islands: Priority Sites for Conservation.(L.D.C.
Fishpool and M.I. Evans, ed.), pp. 3677-390. Newbury and Cambridge, UK. Pisces Publications and BirdLife International (BirdLife Conservation Series No. 11).

Oteng-Yeboah A. A. (1997). Modern Concepts of Biodiversity: An Overview of Agenda 21. Paper presented at a UNESCOMAB Seminar on Biosphere Reserves for Biodiversity Conservation and Sustainable Development in Anglophone Africa (BRAAF), Cape Coast, Ghana.

Population Reference Bureau (PRB) (2000). World Population DataSheet: Demographic Data and Estimates for the Countries and Regions of the World. Washington DC.

Sarpong G. A. (1996). The Environmental Protection Agency Act: Implications for Managing Directors and Heads of Organizations. Paper Presented at a Seminar on Environmental Protection in Ghana.

Secretariat of the Convention on Biological Diversity (SCBD) (2001). Handbook of the Convention on Biological Diversity. Earthscan Publications, London, UK.

Songsore J. (1992). The ERP/Structural Adjustment Programme: Their Likely Impact on the "Distant" Rural Poor in Northern Ghana. In Planning African Growth and Development: Some Current Issues (E. Aryeetey, ed.), pp. 154-170. ISSER/UNDP Publication, Accra.

Stork N. E. and Samways M. J. (ed.). (1995). Inventorying and Monitoring Biodiversity, In Global Biodiversity Assessment (V. H. Heywood, ed.), pp. 453-544. Cambridge University Press, Cambridge.

United Nations Environment Programme (UNEP) (1992). Convention on Biological Diversity Text and Annexes. Secretariat to the CBD, Geneva.

Wildlife Division (WD) (1998). Community Participation in Wildlife Management. Wildlife Development Plan, Accra, Ghana. 